\title{
Hepatoprotective and nephroprotective effects of Trigonella foenum-graecum L. (Fenugreek) seed extract against sodium nitrite toxicity in rats
}

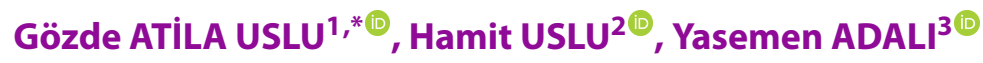

${ }^{1}$ Department of Physiology, Faculty of Veterinary Medicine, University of Kafkas, Kars - Turkey

${ }^{2}$ Department of Health Care Services, Atatürk Vocational School of Health Services, University of Kafkas, Kars Turkey

${ }^{3}$ Department of Pathology, Faculty of Medicine, University of Çanakkale Onsekiz Mart, Çanakkale - Turkey

\section{Correspondence}

Gözde ATILA USLU, Department of Physiology, Faculty of Veterinary Medicine, University of Kafkas, Kars Turkey

Email: gzd.gozde@hotmail.com

History

- Received: Feb 12, 2019

- Accepted: Apr 30, 2019

- Published: May 30, 2019

DOI :

https://doi.org/10.15419/bmrat.v6i5.540

\section{Check for updates}

\section{Copyright}

(c) Biomedpress. This is an openaccess article distributed under the terms of the Creative Commons Attribution 4.0 International license.

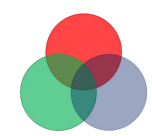

\begin{abstract}
Introduction: Feeding habits and environmental factors may rival genetic susceptibility as etiological factors related to various cancers. Humans are continuously exposed to many synthetic food additives, one of which is sodium nitrite $\left(\mathrm{NaNO}_{2}\right)$. There is a direct correlation between increases in consumption of nitrite-treated products and incidence of tissue damage, hepatotoxicity, nephrotoxicity and some types of cancer. The objective of this study was to investigate the protective effects of Trigonella foenum-graecum (TFG) on $\mathrm{NaNO}_{2}$-induced hepatotoxicity and nephrotoxicity. Methods: Forty rats were randomly assigned (10 per group) to control (physiological saline solution), TFG (150 mg/kg/day), $\mathrm{NaNO}_{2}\left(80 \mathrm{mg} / \mathrm{kg} /\right.$ day), and $\mathrm{NaNO}_{2}+\mathrm{TFG}(80 \mathrm{mg} / \mathrm{kg} /$ day +150 $\mathrm{mg} / \mathrm{kg} /$ day) groups. This group was offered TFG seed extract two hours before $\mathrm{NaNO}_{2}$. At the end of three months, the rats were decapitated, and blood, kidney and liver tissues were removed. Results: Three months of oral administration of $\mathrm{NaNO}_{2}$ increased serum aspartate aminotransferase (AST), alanine aminotransferase (ALT), urea, creatinine, and pro-inflammatory cytokine levels in the liver and kidney tissues [except for liver Interleukin 1 alpha (IL-1 $\alpha)$ ] of rats. Serum AST, ALT, urea, creatinine, liver IL-6, and kidney tumor necrosis factor- $\alpha$ (TNF- $\alpha$ ), IL-6, IL-1 $\alpha$ levels significantly decreased in the $\mathrm{NaNO}_{2}+\mathrm{TFG}$ group compared to the $\mathrm{NaNO}_{2}$ group. Pathological examinations, it was determined show that exogenously administered TFG could alleviate the effects of $\mathrm{NaNO}_{2}$ hepatotoxicity and nephrotoxicity. Conclusions: Our results suggest that exogenous TFG mitigates $\mathrm{NaNO}_{2}$-administration induced hepatotoxicity and nephrotoxicity. TFG extract exerted antioxidative and anti-inflammatory effects, and played a significant role in preventing hepatic and renal damage induced by chronic $\mathrm{NaNO}_{2}$ administration.
\end{abstract}

Key words: Hepatotoxicity, Nephrotoxicity, Pro-inflammatory cytokine, Sodium nitrite, Trigonella foenum-graecum

\section{INTRODUCTION}

Much research has been devoted to determining the relationship between diet and chronic diseases like diabetes, cancer, coronary heart disease, metabolic syndrome and osteoporosis. Humans are continuously exposed to many synthetic food additives, one of which is sodium nitrite $\left(\mathrm{NaNO}_{2}\right) . \mathrm{NaNO}_{2}$ inhibits bacterial growth secondary to colour preservatives, improves flavour, and extends the shelf-life of meat and fish products ${ }^{1,2}$. Unfortunately, high levels of $\mathrm{NaNO}_{2}$ intake may increase the risks of cancer, hepatotoxicity, nephrotoxicity, inflammation, oxidative stress, and tissue injury ${ }^{3,4}$. The toxic effects of $\mathrm{NaNO}_{2}$ are due to the production of nitrosamines and nitroamides when nitrites react with amines and amides in food ${ }^{5-7}$. The resulting nitrosamines and nitroamides also increase the production of free radi$\mathrm{cals}^{8}$. Intestinal bacteria with nitrite reductase activity may increase the production of nitric oxide (NO) from nitrites ${ }^{9,10}$. Akhzari et al. (2019) reported that alanine aminotransferase (ALT), alkaline phosphatase (ALP), caspase-3 activities, malondialdehyde (MDA), TNF- $\alpha$ and transforming growth factor- $\beta 1$ levels increased and reduced glutathione (GSH), glutathione reductase (GR) and glutathione peroxidase (GPx) levels decreased in rats treated with sodium nitrite ${ }^{11}$. Another study determined that $\mathrm{NaNO}_{2}$ increased lipid peroxidation, MDA, NO levels, arginase activity but decreased activity of GSH and catalase (CAT) toxicity induced by sodium nitrite in rats ${ }^{6}$. Also, Ansari et al. (2019) indicated that $\mathrm{NaNO}_{2}-$ induced oxidative stress causes a decrease in the activity of antioxidant defence system, brush border membrane and metabolic enzymes in kidneys ${ }^{12}$.

There is a growing interest in the use of plant-derived agents for treating diseases and/or preventing chronic health conditions. Trigonella foenum-graecum $\mathrm{L}$. (fenugreek or TFG) is an annual plant that belongs 
to the Leguminosae family ${ }^{13}$. Its seeds and leaves are commonly used as a condiment and seasoning, and a wheat and maize flour supplement for bread-making. Additionally, TFG is a staple food in Asian and North African regions ${ }^{14}$ and is also used in traditional medicine owing to its antidiabetic, hypoglycaemic, antioxidant, hypolipidemic and immunomodulatory effects $^{15,16}$. The most important phytochemicals isolated from TFG are saponins, trigonelline alkaloids, trigocoumarin, phosphates, potassium, proteins (4-hydroxyisoleucine), choline, vitamin C, betacarotene, nicotinic acid, and folic acid ${ }^{15,17}$. TFG may mitigate the adverse effects of $\mathrm{NaNO}_{2}$ administration. This study investigate the protective effects of TFG on $\mathrm{NaNO}_{2}$-induced hepatotoxicity and nephrotoxicity were investigated.

\section{METHODS}

\section{Extraction of plant material}

TFG seeds were purchased at a local herbal market. Mature fruits were collected between August and September and then sundried. After this process the seeds become yellow and light brown. Each seed is4-6 $\mathrm{mm}$ long and 2-3 $\mathrm{mm}$ width. They are slightly rough, squared or rectangular and unevenly shaped. We pulverated $1000 \mathrm{~g}$ of the seeds into a fine powder and dissolved this powder into a mixture of ethyl alcohol and water (2:8) at a ratio of 1:5 (seed weight: solvent volume $)^{18}$. The mixture was kept at room temperature in a shaking water bath for 2 days. It was filtered through filter paper, and the excess solvents were evaporated under pressure at $50^{\circ} \mathrm{C}$. We obtained $9 \mathrm{~g}$ of the extract from $250 \mathrm{ml}$ of macerated seeds.

\section{Experimental design}

We used 40 female Wistar Albino rats, aged around 2 months. The rats were divided equally into four groups (10 rats per group) for the experiments. The animals were maintained under standard conditions [temperatures $\left(23 \pm 2^{\circ} \mathrm{C}\right)$, humidity $(55 \pm 5 \%)$ and 12 hrs light: 12 hrs dark cycle] and were fed standard laboratory chow (Moisture: 12.8\%, crude protein: $23.1 \%$, crude cellulose: $5 \%$, crude oil: $2.8 \%$, crude ash: $7.1 \%$, and sodium $0.60 \%$ ). The rats were allowed tap water ad libitum throughout the experiment. The animal protocol was accepted by the ethical committee for Animal Experiments at Kafkas University.

Control group (C): This group received oral physiological saline solution $(300 \mu \mathrm{L} /$ day $)$.

Trigonella foenum-graecum group (TFG): This group received $150 \mathrm{mg} / \mathrm{kg} /$ day TFG seed extract dissolved in water.
Sodium nitrite group $\left(\mathrm{NaNO}_{2}\right)$ : This group received $80 \mathrm{mg} / \mathrm{kg} /$ day $\mathrm{NaNO}_{2}$ dissolved in water.

Sodium nitrite + Trigonella foenum-graecum group $\left(\mathrm{NaNO}_{2}+\mathrm{TFG}\right)$ : This group received $150 \mathrm{mg} / \mathrm{kg} /$ day TFG seed extract 60 minutes prior to $80 \mathrm{mg} / \mathrm{kg} /$ day $\mathrm{NaNO}_{2}$.

Rats were administered with $\mathrm{NaNO}_{2}$, TFG extract and physiological saline solution by oral gavage over three months. The dose and duration of $\mathrm{NaNO}_{2}$ and TFG extract used in this study were in the range of those used in other studies, and of the same animal species $^{19-21}$.

\section{Biochemical analysis and Histopathologi- cal evaluations}

At the end of the experiment, blood samples were collected under $0.4 \mathrm{ml} / \mathrm{kg}$ pentobarbital sodium anaesthesia via the intracardiac route. Blood samples were taken with a non-anticoagulant tube and then centrifuged at $1000 \mathrm{xg}$ for $15 \mathrm{~min}$ at $4^{\circ} \mathrm{C}$ to produce serum. The serum aspartate aminotransferase (AST), alanine aminotransferase (ALT) (Mindray BS 120), urea and creatinine levels (Architect c16000 Abbott Diagnostic-USA model) were measured using an autoanalyser. The rat livers and kidneys were removed quickly and cleaned with cold physiological saline solution. Pieces of the livers and kidneys were homogenised in a 10-fold volume of phosphate buffered saline. We used ELISA kits to determine proinflammatory cytokine (IL-6, IL- $1 \alpha$, TNF- $\alpha$ ) levels in tissue homogenates (Elabscience WuHan-P.R.C). Moreover, some tissues were fixed in $10 \%$ formalin and processed according to standard procedures. We cut $4-\mu$ m-thick paraffin sections, stained them with haematoxylin-eosin and evaluated the results using a light microscope.

\section{Statistical analysis}

We used a one-way ANOVA to determine whether there were significant differences among the groups. The Tukey multiple range test was used to detect significant pairwise differences between the groups. A value of $\mathrm{p}<0.05$ was considered significant. All statistical tests were performed using SPSS 18 .

\section{RESULTS}

We evaluated the hepatoprotective and nephroprotective effects of TFG seed extract by measuring the serum activities of ALT, AST, urea and creatinine. Rats administered $\mathrm{NaNO}_{2}$ showed significant increases in serum ALT compared to the C and TFG groups $(p<0.05)$. We found a significant increase in 
the AST levels in the $\mathrm{NaNO}_{2}$ group relatively to the $\mathrm{C}$ and TFG groups $(\mathrm{p}<0.001)$. Moreover, there was a significant decrease in AST levels in the TFG group when compared to the $\mathrm{C}$ group $(\mathrm{P}<0.01)$. Administration of $\mathrm{NaNO}_{2}$ with TFG seed extract (NaNO2+TFG) significantly decreased serum AST and ALT levels compared to the $\mathrm{NaNO}_{2}$ group ( $<<0.001, \mathrm{p}<0.05$ respectively). A significant increase in urea levels were observed in the $\mathrm{NaNO}_{2}$ and $\mathrm{NaNO}_{2}+\mathrm{TFG}$ groups compared to the $\mathrm{C}$ and TFG groups $(\mathrm{p}<0.001, \mathrm{p}<0.01$ respectively). Serum urea levels were also significantly lower in the $\mathrm{NaNO}_{2}+\mathrm{TFG}$ group, compared to the $\mathrm{NaNO}_{2}$ group $(\mathrm{p}<0.05)$. Both the $\mathrm{NaNO}_{2}$ and $\mathrm{NaNO}_{2}+\mathrm{TFG}$ groups exhibited significantly higher serum creatinine levels compared to the $\mathrm{C}$ and TFG groups ( $\mathrm{p}<0.001, \mathrm{p}<0.05$ respectively). Moreover, the serum creatinine levels were significantly decreased in the $\mathrm{NaNO}_{2}+\mathrm{TFG}$ group, as compared to the $\mathrm{NaNO}_{2}$ group $(\mathrm{p}<0.05)$ (Figure 1).

$\mathrm{NaNO}_{2}$ significantly increased liver TNF- $\alpha$ and IL6 levels compared to the $\mathrm{C}$ and TFG groups ( $\mathrm{p}<0.05$, $\mathrm{p}<0.001$ respectively), yet, did not affect the IL- $1 \alpha$. Chronic treatment with $\mathrm{TFG}+\mathrm{NaNO}_{2}$ significantly decreased IL- 6 in liver tissues of rats, compared with the $\mathrm{NaNO}_{2}$ group $(\mathrm{p}<0.01)$. However, IL-6 increased in $\mathrm{TFG}+\mathrm{NaNO}_{2}$ group compared to $\mathrm{C}$ group $(\mathrm{p}<0.05)$ (Figure 2). $\mathrm{NaNO}_{2}$ administration increased kidney TNF- $\alpha$, IL- 6 and IL- $1 \alpha$ levels when compared to the control group $(\mathrm{p}<0.05, \mathrm{p}<0.001$ and $\mathrm{p}<0.01$ respectively). Our results showed that the TFG+NaNO group exhibited significantly decreased kidney TNF$\alpha$ and IL- 6 levels comparing to with the $\mathrm{NaNO}_{2}$ group $(\mathrm{p}<0.05)$ (Figure 3).

Histopathological examination revealed hepatocyte damage of variable prevalence and intensities in all $\mathrm{NaNO}_{2}$ group rats. Also, in the TFG $+\mathrm{NaNO}_{2}$ group, half of the rats had hepatocyte damage (Figure 4). In the $\mathrm{C}$ group, we observed mild congestion in only one kidney tissue sample. In the $\mathrm{NaNO}_{2}$ group, most of the cases had focal tubular epithelial damage, mild vascular congestion in one of these damaged cases and the least severe inter and intratubular haemorrhage in the damaged cases. There was one case of mild violent intratubular haemorrhage in the TFG group. In the $\mathrm{TFG}+\mathrm{NaNO}_{2}$ group, mild severe vascular congestion and mild severe intermittent haemorrhage was detected in one of the cases with mild severe focal tubular epithelial damage in most of the cases (Figure 5). We therefore conclude that exogenouslyadministered TFG may alleviate the effects of $\mathrm{NaNO}_{2}$ hepatotoxicity and nephrotoxicity.

\section{DISCUSSION}

$\mathrm{NaNO}_{2}$ is an important food additive with antibacterial properties for pathogens such as $\mathrm{Cl}$. botulinum, Listeria monocytogenes, Escherichia coli O157:H7 and Salmonella ${ }^{22-24}$. However, because high doses and chronic $\mathrm{NaNO}_{2}$ consumption increase the levels of carcinogenic N-nitrosamines, restricted dietary intake should be considered ${ }^{25,26}$. Prolonged oral administration of $\mathrm{NaNO}_{2}$ has been shown to result in widespread and moderate inflammation and damage in rats. Previous studies support our findings ${ }^{2,4,27}$. However, oral administration of $\mathrm{TFG}+\mathrm{NaNO}_{2}$ significantly reduced hepatic and renal damage and inflammation compared to the $\mathrm{NaNO}_{2}$ group. TFG mitigates various toxicities, but there is no published literature on the effects of TFG extract on $\mathrm{NaNO}_{2}$ toxicity. This study presented an important step in this regard. TFG extract exerted positive effects on alcohol ${ }^{28}$, acrylamide ${ }^{29}$, and cyclophosphamide + buthionine-SR-sulfoximine ${ }^{30}$ toxicity in previous studies. The seeds also have hypoglycaemic ${ }^{31}$, antiinflammatory $^{32}$, antiulcerogenic ${ }^{33}$, and antinociceptive $^{34}$ effects. In another study, both hepatic and testicular dysfunction were found in male rats exposed to chronic cadmium, but the application of fenugreek seed powder was beneficial for these disorders $^{35}$. Thirunavukkarasu et al. (2003) found that aqueous extract of TFG may protect against damage to lipid peroxidation and liver and brain tissue damage $^{36}$. Belaiid-Nouira et al. (2013) found that treatment with fenugreek seed powder normalises plasma markers and alleviates histopathological changes in cases with aluminium-induced kidney damage ${ }^{37}$.

Serum enzymes including AST, ALT, urea and creatinine are used to evaluate patients with hepatic and renal disorders. This enzymes activity increases in cases of liver and kidney damage ${ }^{38} . \mathrm{NaNO}_{2}$ reacts with amines in the stomach, producing nitrosamines that cause serious damage to the liver and kidneys ${ }^{39}$. $\mathrm{NaNO}_{2}$ administration can alter liver and kidney function, as evidenced by significant increases in AST, ALT, urea and creatinine, compared to group C. TFG seed extract lowers levels of key enzymes that characterise liver and kidney damage.

$\mathrm{NaNO}_{2}$ initiates peroxidative damage in cells and increases the activation of pro-inflammatory cytokines $^{40}$. Therefore, pro-inflammatory cytokines may play an important role in the formation of liver and kidney damage. Al-Gayyar et al. (2014) found that $\mathrm{NaNO}_{2}$ increased levels of cardiac proinflammatory cytokines and decreased levels of antiinflammatory cytokines ${ }^{1}$. Another study determined that $\mathrm{NaNO}_{2}$ caused renal toxicity and significantly increased oxidative stress, inflammation, 


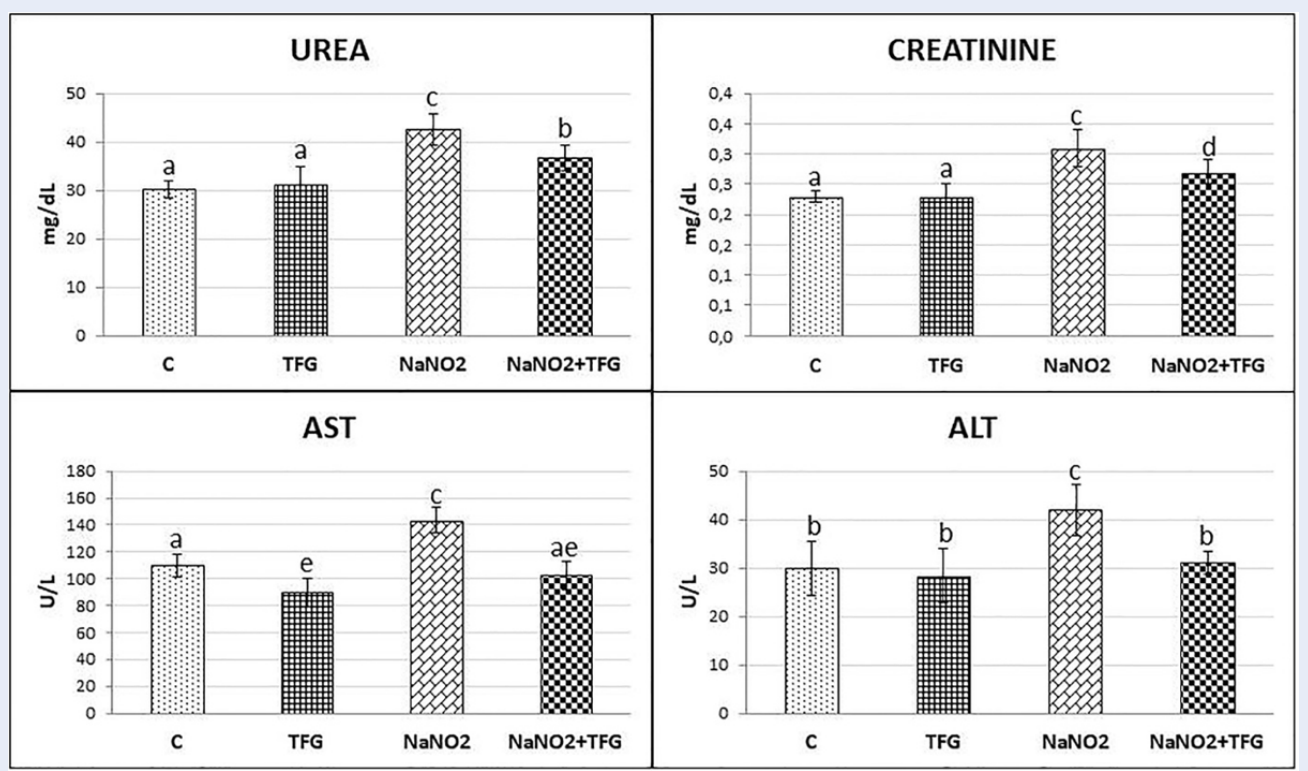

Figure 1: Effect of TFG extract on serum Urea $(\mathrm{mg} / \mathrm{dL})$ and Creatinine $(\mathrm{mg} / \mathrm{dL})$ levels, AST (U/L), ALT (U/L) mean \pm SD of animals in each group (n:10). a-b, a-e: $p<0.01$, a-c, c-e, c-ae: $p<0.001, a-d, b-c, c-d: p<0.05$.

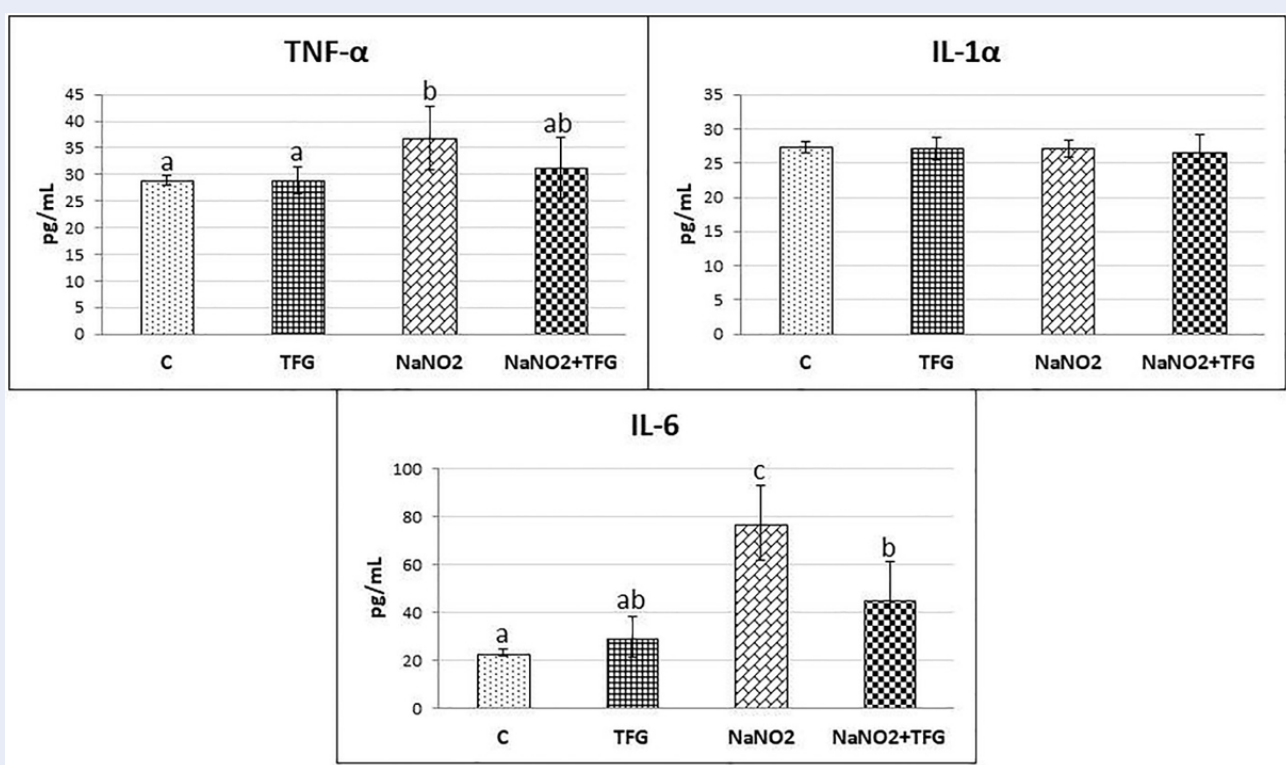

Figure 2: Effect of TFG extract on liver proinflammatory cytokines (IL-6, IL-1 $\alpha$, TNF- $\alpha$ ) levels (pg/mL), mean \pm SD of animals in each group. $a-b: p<0.05, b-c: p<0.01, a-c, a b-c: p<0.001$ 


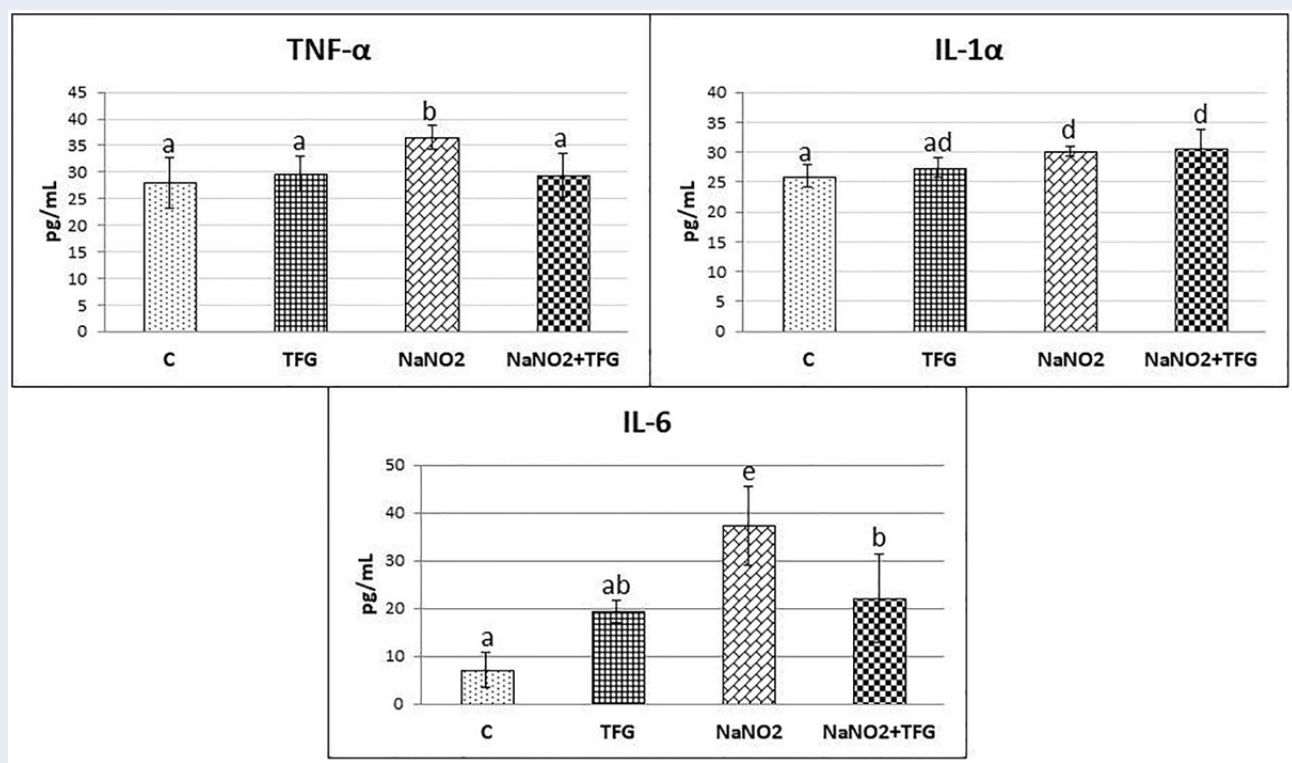

Figure 3: Effect of TFG extract on kidney proinflammatory cytokines (IL-6, IL-1 $\alpha$, TNF- $\alpha$ ) levels (pg/mL), mean \pm SD of animals in each group. $a-b, b-e: p<0.05, a-d, a b-e: p<0.01$, a-e: $p<0.001$.

and apoptosis markers ${ }^{41}$. In the present study, we determined that $\mathrm{NaNO}_{2}$ caused serious damage to liver and kidney tissues and led to significant increases in pro-inflammatory cytokine levels in these tissues. TFG seed extract reduced liver and kidney damage induced by $\mathrm{NaNO}_{2}$, and reduced proinflammatory cytokine levels, especially in the kidneys. Previous studies showed that TFG seeds are a rich source of polyphenols. Polyphenols such as apigenin, kaempferol, quercetin, vitexin and tricine, were identified by HPLC ${ }^{42,43}$. Also, sapogenins, diosgenin, 4-hydroxy-isoleucine, trigonelline, alkaloids, phosphate, potassium, copper, protein, choline, vitamin $\mathrm{C}$, beta carotene, nicotinic acid and folic acid are active chemical components of $\mathrm{TFG}^{44-46}$. BinHafeez et al. (2013) reported that the immunostimulatory activity of TFG is mediated by the saponins, fibres and flavonoids it contains ${ }^{15}$. The toxic effects of $\mathrm{NaNO}_{2}$ are caused by the production of nitrosamines and nitrosamides, which are known to cause tissue damage due to inflammation and oxidative stress. In this study, TFG extract was found to cause significant decreases in liver and kidney damage markers and pro-inflammatory cytokine levels in $\mathrm{NaNO}_{2}$-induced hepatotoxicity and nephrotoxicity. It is proposed that TFG performs hepato and nephroprotective effects with immunostimulatory factors found in previous studies.

\section{CONCLUSIONS}

In conclusion, chronic $\mathrm{NaNO}_{2}$ consumption causes severe physiological and histopathological changes in liver and kidney tissues in rats. The TFG extract showed antioxidant and anti-inflammatory effects, and prevented hepatic and renal damage induced by chronic $\mathrm{NaNO}_{2}$ administration.

\section{ABBREVIATIONS}

ALP: Alkaline phosphatase

ALT : Alanine aminotransferase

AST : Aspartate aminotransferase

CAT: Catalase

GPx: Glutathione peroxidase

GR: Glutathione reductase

GSH: Reduced glutathione

IL-1 $\alpha$ : Interleukin 1 alpha

IL-6 : Interleukin-6

MDA: Malondialdehyde

NO: Nitric oxide

TFG : Trigonella foenum-graecum

TNF- $\alpha$ : Tumor necrosis factor alpha

\section{COMPETING INTERESTS}

The authors declare no conflict of interest.

\section{AUTHORS' CONTRIBUTIONS}

The design, experimental part and biochemical analysis of the study were carried out by Dr. Gözde ATILA 

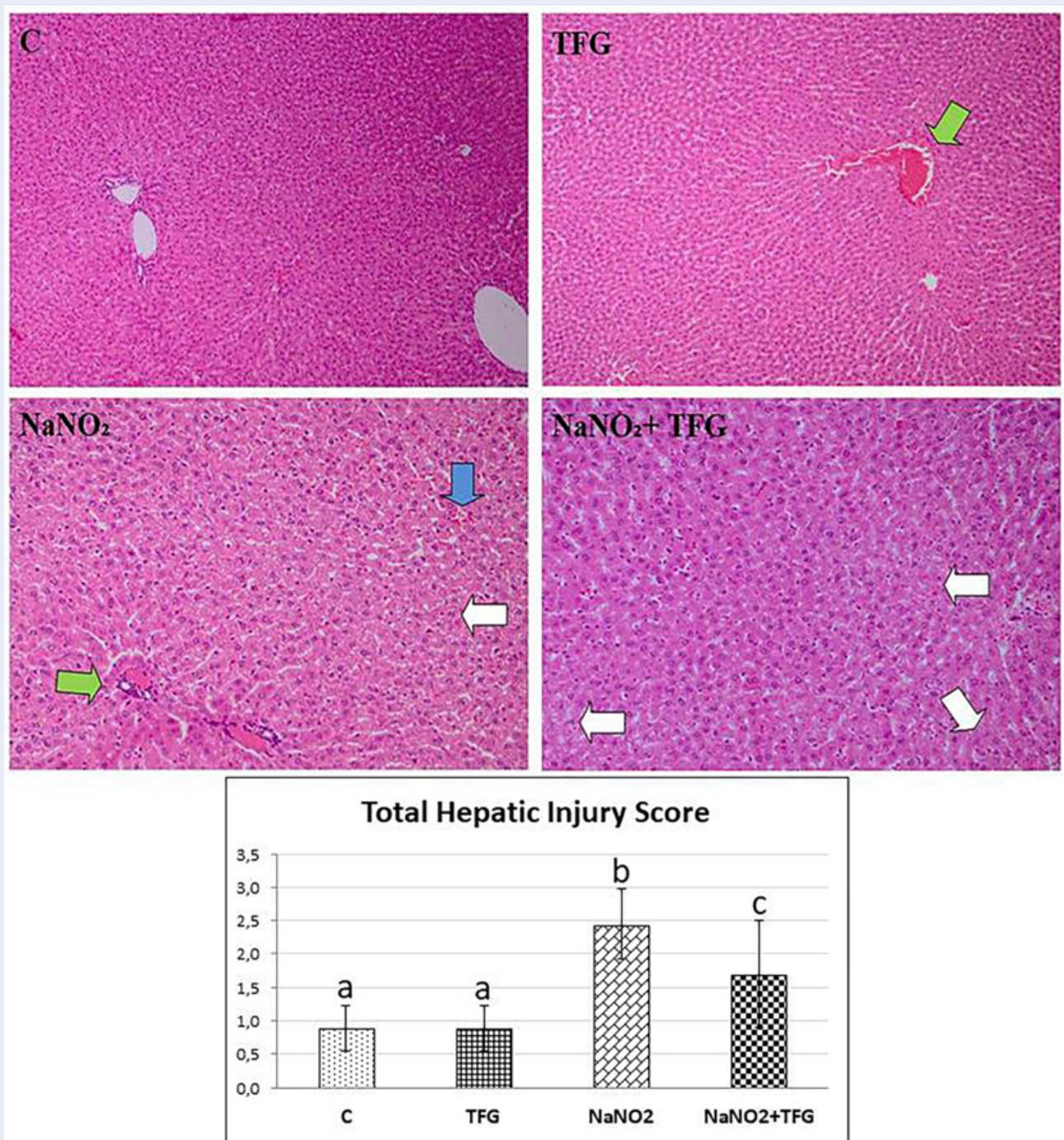

Figure 4: Focal moderate hepatocyte damage (white arrow), interhepatocytic hemorrhage (blue arrow) and vascular congestion (green arrow), H \& E-200x. a-b:p $<0.001, a-c, b-c: p<0.05$

USLU and Dr. Hamit USLU. The histopathological evaluations were performed by Dr. Yasemen ADALI. All the authors took equal roles in writing the research.

\section{ACKNOWLEDGMENTS}

This study was awarded the best oral presentation award in the field of veterinary medicine in the second international science symposium (science festival) held in Tbilisi / Georgia on 05-08 September 2017.

\section{REFERENCES}

1. Al-Gayyar MM, Youssef AA, Sherif IO, Shams ME, Abbas A. Protective effects of arjunolic acid against cardiac toxicity induced by oral sodium nitrite: effects on cytokine balance and apoptosis. Life Sci. 2014;111(1-2):18-26. 25064822. Available from: 10.1016/j.lfs.2014.07.002.

2. Salama MF, Abbas A, Darweish MM, El-Hawwary AA, Al-Gayyar MM. Hepatoprotective effects of cod liver oil against sodium nitrite toxicity in rats. Pharm Biol. 2013;51(11):1435-43. 23862714. Available from: 10.3109/13880209.2013.796564.

3. Alyoussef A, Al-Gayyar MM. Thymoquinone ameliorated elevated inflammatory cytokines in testicular tissue and sex hormones imbalance induced by oral chronic toxicity with sodium nitrite. Cytokine. 2016;83:64-74. 27038016. Available from: 10.1016/j.cyto.2016.03.018.

4. Al-Gayyar MM, Hassan HM, Alyoussef A, Abbas A, Darweish MM, El-Hawwary AA. Nigella sativa oil attenuates chronic nephrotoxicity induced by oral sodium nitrite: effects on tissue fibrosis and apoptosis. Redox Rep. 2016;21(2):50-60. 26221999.

5. Abdeen AM, El-Shayeb AF, Hassan HA, El-Agamy SA. The Protective Role of Garlic Oil Against the Histopathological and Histochemical Changes Induced by Sodium Nitrite Toxicity 

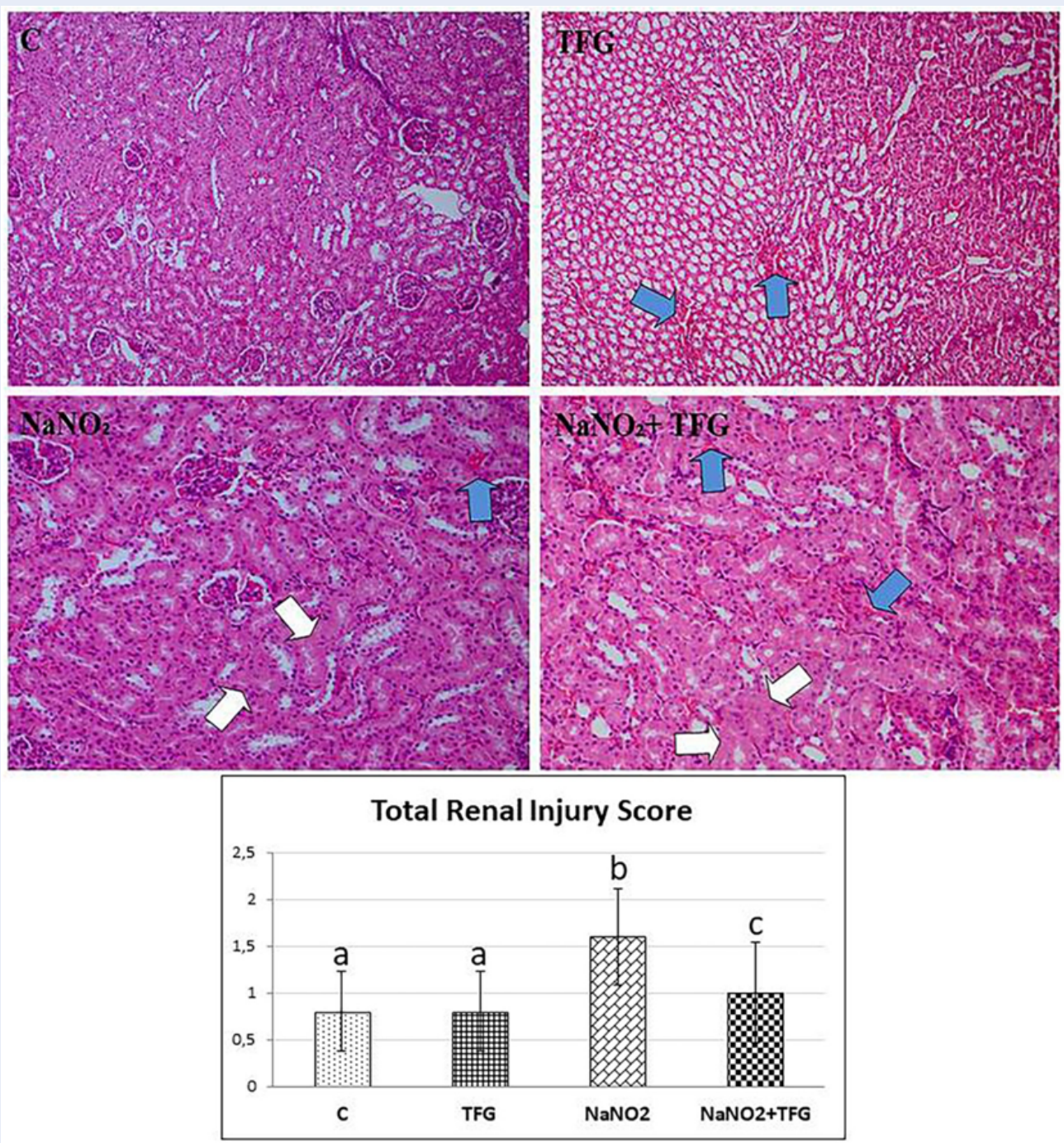

Figure 5: Tubular epithelial cell damage (white arrow) andinter tubular bleeding areas (blue arrow), H \& E 200x. a-b: $p<0.01, b-c: p<0.05, a-c: p>0.05$

in Kidneys of Albino Rats. J Jazan Univ Appl Sci Branch. 2015:4(1):57-67.

6. El-Sheikh NM, Khalil FA. L-arginine and L-glutamine as immunonutrients and modulating agents for oxidative stress and toxicity induced by sodium nitrite in rats. Food Chem Toxicol. 2011;49(4):758-62. 21130833. Available from: 10.1016/j. fct.2010.11.039.

7. Tong $M$, Longato $L$, de la Monte SM. Early limited nitrosamine exposures exacerbate high fat diet-mediated type 2 diabetes and neurodegeneration. BMC Endocr Disord. 2010;10(1):4. 20302640. Available from: 10.1186/1472-6823-10-4.

8. Hassan HA, Yousef MI. Ameliorating effect of chicory (Cichorium intybus L.)-supplemented diet against nitrosamine precursors-induced liver injury and oxidative stress in male rats. Food Chem Toxicol. 2010:48(8-9):2163-9. 20478349. Available from: 10.1016/j.fct.2010.05.023.

9. Duncan $C$, Dougall $H$, Johnston $P$, Green $S$, Brogan R, Leifert $C$, et al. Chemical generation of nitric oxide in the mouth from the enterosalivary circulation of dietary nitrate. Nat Med. 1995;1(6):546-51. 7585121. Available from: 10.1038/nm0695-
546.

10. El-Wakf AM, Hassan HA, Mahmoud AZ, Habza MN. Fenugreek potent activity against nitrate-induced diabetes in young and adult male rats. Cytotechnology. 2015;67(3):437-47. 24615531. Available from: 10.1007/s10616-014-9702-7.

11. Akhzari M, Shafiee SM, Rashno S, Akmali M. Berberine Attenuated Oxidative Stress Induced by Sodium Nitrite in Rat Liver. Jundishapur J Nat Pharm Prod. 2019;14(1):e68532. Available from: 10.5812/jjnpp.68532.

12. Ansari FA, Khan AA, Mahmood R. Ameliorative effect of carnosine and $\mathrm{N}$-acetylcysteine against sodium nitrite induced nephrotoxicity in rats. J Cell Biochem. 2018;120(5):7032-44. 30368897. Available from: 10.1002/jcb.27971.

13. Eidi A, Eidi M, Sokhteh M. Effect of fenugreek (Trigonella foenum graecum L.) seeds on serum parameters in normal and streptozotocin-induced diabetic rats. Nutr Res. 2007;27(11):728-33. Available from: 10.1016/j.nutres.2007.09. 006.

14. Xue WL, Li XS, Zhang J, Liu YH, Wang ZL, Zhang RJ. Effect of Trigonella foenum-graecum (fenugreek) extract on 
blood glucose, blood lipid and hemorheological properties in streptozotocin-induced diabetic rats. Asia Pac J Clin Nutr. 2007;16(1):422-6. 17392143.

15. Bin-Hafeez B, Haque R, Parvez S, Pandey S, Sayeed I, Raisuddin S. Immunomodulatory effects of fenugreek (Trigonella foenum graecum L.) extract in mice. Int Immunopharmacol. 2003;3(2):257-65. 12586606. Available from: 10.1016/S15675769(02)00292-8.

16. Renuka C, Ramesh N, Saravanan K. Evaluation of the antidiabetic effect of Trigonella foenum graecum seed powder on alloxan induced diabetic albino rats. Int J Pharm Tech Res. 2009;1(4):1580-4.

17. Petit PR, Sauvaire YD, Hillaire-Buys DM, Leconte OM, Baissac YG, Ponsin GR, et al. Steroid saponins from fenugreek seeds: extraction, purification, and pharmacological investigation on feeding behavior and plasma cholesterol. Steroids. 1995;60(10):674-80. 8539775. Available from: 10.1016/0039128X(95)00090-D.

18. Hamza N, Berke B, Cheze C, Garrec RL, Umar A, Agli AN, et al. Preventive and curative effect of Trigonella foenumgraecum L. seeds in C57BL/6J models of type 2 diabetes induced by high-fat diet. J Ethnopharmacol. 2012;142(2):51622. 22633967. Available from: 10.1016/j.jep.2012.05.028.

19. Hassan HA, Hafez HS, Zeghebar FE. Garlic oil as a modulating agent for oxidative stress and neurotoxicity induced by sodium nitrite in male albino rats. Food Chem Toxicol. 2010;48(7):1980-5. 20457208. Available from: 10.1016/j.fct. 2010.05.001.

20. Mokhtari M, Shariatie M, Gharamanie R. Effect of Trigonella foenum-graecum $L$. seed extract on concentration of testosterone and spermatogenesis in rats. JMP. 2008;1:12-20.

21. Morani AS, Bodhankar SL, Mohan V, Thakurdesai PA. Ameliorative effects of standardized extract from Trigonella foenumgraecum L. seeds on painful peripheral neuropathy in rats. Asian Pac J Trop Med. 2012;5(5):385-90. 22546656. Available from: 10.1016/S1995-7645(12)60064-9.

22. Duffy LL, Vanderlinde PB, Grau FH. Growth of Listeria monocytogenes on vacuum-packed cooked meats: effects of $\mathrm{pH}$, aw, nitrite and ascorbate. Int J Food Microbiol. 1994;23(3-4):37790. 7873338. Available from: 10.1016/0168-1605(94)90164-3.

23. Dykhuizen RS, Frazer R, Duncan C, Smith CC, Golden M, Benjamin $\mathrm{N}$, et al. Antimicrobial effect of acidified nitrite on gut pathogens: importance of dietary nitrate in host defense. Antimicrob Agents Chemother. 1996;40(6):1422-5. 8726013. Available from: 10.1128/AAC.40.6.1422.

24. Milkowski A, Garg HK, Coughlin JR, Bryan NS. Nutritional epidemiology in the context of nitric oxide biology: a riskbenefit evaluation for dietary nitrite and nitrate. Nitric Oxide. 2010;22(2):110-9. 19748594. Available from: 10.1016/j.niox. 2009.08.004.

25. Kozisek F. Influence of nitrate levels in drinking water on urological malignancies: a community-based cohort study. BJU Int. 2007;99(6):1550-1. 17537226. Available from: 10.1111/j. 1464-410X.2007.06970_4.x.

26. Ward MH, Pan WH, Cheng YJ, Li FH, Brinton LA, Chen CJ, et al. Dietary exposure to nitrite and nitrosamines and risk of nasopharyngeal carcinoma in Taiwan. Int J Cancer. 2000;86(5):603-9. 10797279. Available from: 10.1002/(SICI) 1097-0215(20000601)86:5<603::AID-IJC1>3.0.CO;2-H.

27. Sherif IO, Al-Gayyar MM. Antioxidant, anti-inflammatory and hepatoprotective effects of silymarin on hepatic dysfunction induced by sodium nitrite. Eur Cytokine Netw. 2013;24(3):114-21. 24225033.

28. Kaviarasan S, Ramamurty N, Gunasekaran P, Varalakshmi E, Anuradha CV. Fenugreek (Trigonella foenum graecum) seed extract prevents ethanol-induced toxicity and apoptosis in Chang liver cells. Alcohol Alcohol. 2006;41(3):267-73. 16574673. Available from: 10.1093/alcalc/agl020.

29. Abdel-Daim MM, Eldaim MAA, Hassan AG. Trigonella foenumgraecum ameliorates acrylamide-induced toxicity in rats: roles of oxidative stress, proinflammatory cytokines, and DNA damage. Biochem Cell Biol. 2015;93(3):192-8. 25607344.
Available from: 10.1139/bcb-2014-0122.

30. Bhatia K, Kaur M, Atif F, Ali M, Rehman H, Rahman S, et al. Aqueous extract of Trigonella foenum-graecum $\mathrm{L}$. ameliorates additive urotoxicity of buthionine sulfoximine and cyclophosphamide in mice. Food Chem Toxicol. 2006;44(10):1744-50. 16828947. Available from: 10.1016/j.fct.2006.05.013.

31. Puri D, Prabhu KM, Murthy PS. Mechanism of action of a hypoglycemic principle isolated from fenugreek seeds. Indian J Physiol Pharmacol. 2002;46(4):457-62. 12683221.

32. Mandegary A, Pournamdari M, Sharififar F, Pournourmohammadi S, Fardiar R, Shooli S. Alkaloid and flavonoid rich fractions of fenugreek seeds (Trigonella foenum-graecum L.) with antinociceptive and anti-inflammatory effects. Food Chem Toxicol. 2012;50(7):2503-7. 22542922. Available from: 10 1016/j.fct.2012.04.020

33. Pandian RS, Anuradha CV, Viswanathan P. Gastroprotective effect of fenugreek seeds (Trigonella foenum graecum) on experimental gastric ulcer in rats. J Ethnopharmacol. 2002;81(3):393-7. 12127242. Available from: 10.1016/S03788741(02)00117-4.

34. Puri D. Therapeutic potentials of fenugreek. Indian J Physiol Pharmacol. 1998;42(3):423-4. 9741661.

35. Arafa MH, Mohammad NS, Atteia HH. Fenugreek seed powder mitigates cadmium-induced testicular damage and hepatotoxicity in male rats. Exp Toxicol Pathol. 2014;66(7):293-300. 24813645. Available from: 10.1016/j.etp.2014.04.001.

36. Thirunavukkarasu V, Anuradha CV, Viswanathan P. Protective effect of fenugreek (Trigonella foenum graecum) seeds in experimental ethanol toxicity. Phytother Res. 2003;17(7):73743. 12916070. Available from: $10.1002 /$ ptr.1198.

37. Bela Y;

38. Hassan HA, El-Agmy SM, Gaur RL, Fernando A, Raj MH, Ouhtit A. In vivo evidence of hepato- and reno-protective effect of garlic oil against sodium nitrite-induced oxidative stress. Int J Biol Sci. 2009;5(3):249-55. 19305642. Available from: 10.7150/ ijbs.5.249.

39. Choi SY, Chung MJ, Sung NJ. Volatile N-nitrosamine inhibition after intake of Korean green tea and Maesil extracts with an amine-rich diet in subjects ingesting nitrate. Food Chem Toxicol. 2002;40(7):949-57. 12065217. Available from: 10.1016/S0278-6915(02)00025-X.

40. Mittal G, Brar AP, Soni G. Impact of hypercholesterolemia on toxicity of $\mathrm{N}$-nitrosodiethylamine: biochemical and histopathological effects. Pharmacol Rep. 2006;58(3):413-9. 16845216.

41. Elsherbiny NM, Maysarah NM, El-Sherbiny M, Al-Gayyar MM. Renal protective effects of thymoquinone against sodium nitrite-induced chronic toxicity in rats: impact on inflammation and apoptosis. Life Sci. 2017;180:1-8. 28495515. Available from: 10.1016/j.lfs.2017.05.005.

42. Kenny O, Smyth TJ, Hewage CM, Brunton NP. Antioxidant properties and quantitative UPLC-MS analysis of phenolic compounds from extracts of fenugreek (Trigonella foenumgraecum) seeds and bitter melon (Momordica charantia) fruit Food Chem. 2013;141(4):4295-302. 23993618. Available from: 10.1016/j.foodchem.2013.07.016.

43. Benayad Z, Gómez-Cordovés C, Es-Safi NE. Characterization of flavonoid glycosides from fenugreek (Trigonella foenumgraecum) crude seeds by HPLC-DAD-ESI/MS analysis. Int J Mol Sci. 2014;15(11):20668-85. 25393509. Available from: 10.3390/ijms151120668.

44. Hamadi SA. Effect of trigonelline and ethanol extract of Iraqi Fenugreek seeds on oxidative stress in alloxan diabetic rabbits. JAUBAS. 2012;12(1):23-6. Available from: 10.1016/j. jaubas.2012.02.003.

45. Sauvaire $Y$, Petit $P$, Broca $C$, Manteghetti $M$, Baissac $Y$, Fernandez-Alvarez J, et al. 4-Hydroxyisoleucine: a novel amino acid potentiator of insulin secretion. Diabetes. 1998;47(2):206-10. 9519714. Available from: 10.2337/diab. 47.2.206.

46. Yoshikawa M, Murakami T, Komatsu H, Murakami N, Yama- 
hara J, Matsuda $\mathrm{H}$. Medicinal foodstuffs. IV. Fenugreek seed.

(1): structures of trigoneosides la, llb, Ila, Illb, IIla, and IIlb,

new furostanol saponins from the seeds of Indian Trigonella foenum-graecum L. Chem Pharm Bull (Tokyo). 1997;45(1):81-

7. 9023970 . Available from: $10.1248 / \mathrm{cpb} .45 .81$.

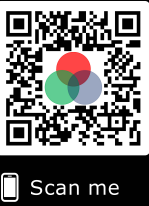

